\title{
Synthesis, Spectroscopic and Thermal Behaviour of Salicylaldimine Complexes
}

\author{
I.S. Ahmed, T.Y. Mohammed" and M.M. Moustafa \\ Chemistry Department, Faculty of Science, Benha University, \\ Benha,Egypt.
}

\begin{abstract}
7 HE COMPLEXES of N-salicylaldimine 2-urea $\left(\mathrm{L}_{1}\right)$ and $\mathrm{N}$ salicylaldimine-2-thiourea $\left(\mathrm{L}_{2}\right)$ with $\mathrm{Fe}(\mathrm{III}), \mathrm{Co}(\mathrm{II}), \mathrm{Ni}(\mathrm{II})$ and $\mathrm{Cu}$ (II) are formed in the molar ratios (1:1) as well as (1:2) (M:L) and characterized by elemental analysis, IR, electronic spectra, thermogravimetric analysis and magnetic measurements. The stoichiometry, proton-reagent stability constant, conditional formation constant of the complexes and the conductance are determined by using potentiometric and conductometric measurements. The study revealed that the ligands behave as monobasic bidentates, electronic spectra and magnetic measurements indicate that the metal chelates have octahedral or square-planar arrangements. Also, the TG analysis indicates the presence of hydrated and coordinated water molecules. The electrolytic and nonelectrolytic nature of the complexes were assigned based on molar conductance measurements.
\end{abstract}

Schiff bases are known for their biological, industrial and analytical importance ${ }^{(1,2)}$. There are reports on the synthesis of transition and inner-transition metal complexes of Schiff bases involving salicylaldehyde and amines, amino acids and aminophenols ${ }^{(3,4)}$. The Schiff bases are of great importance in the complexometric titration ${ }^{(5)}$. The aim of the present investigation is to study the stoichiometry and structure of the complexes formed when $\mathrm{Fe}(\mathrm{III}), \mathrm{Co}(\mathrm{II}), \mathrm{Ni}$ (II) and $\mathrm{Cu}$ (II) salts are allowed to react with salicylaldimine ligand . Also, thermogravimetric analysis of the metal chelates were discussed .

\section{Materials}

\section{Experimental}

All chemicals used were of pure grade $(\mathrm{BDH})$ or Aldrich. The preparation of Schiff base compounds were prepared as reported ${ }^{(6)}$. After recyrstallization from ethanolic solution their purities were confirmed by elemental analysis as well as confirmed by IR and ${ }^{1} \mathrm{H}-\mathrm{NMR}$ spectra. The chemical structure of this is shown in Fig. 1 .

\footnotetext{
*E- mail : Dr_talaat2003@yahoo.com
} 
<smiles>NC(=[V])/N=C/c1ccccc1O</smiles>

Fig.1. Structure of salicylaldimine derivatives $Z=0 ; L_{1}$ (Urea) and $Z=S ; L_{2}$ (Thiourea )

\section{Synthesis of metal chelates}

The metal chelates of the compounds under investigation were synthesized by mixing $20 \mathrm{ml}$ of hot methanolic solutions of $\mathrm{N}$-salicylaldimine-2-urea $\left(\mathrm{L}_{1}\right)$ and $\mathrm{N}$-salicylaldimine-2-thiourea $\left(\mathrm{L}_{2}\right)(0.02 \mathrm{~mol})$ and $20 \mathrm{ml}$ of a methanolic solution of metal salt $(0.02 \mathrm{~mol})$ of $\mathrm{Fe}(\mathrm{III}), \mathrm{Co}(\mathrm{II}), \mathrm{Ni}(\mathrm{II})$ and $\mathrm{Cu}(\mathrm{II})$ chloride. The mixture was left to stand on steam bath for $4 \mathrm{hr}$. In some cases, the metal chelates did not separate on standing and few drops of ammonia solution were added slowly with stirring to adjust the $\mathrm{pH}$ to 6-8 which resulted in precipitation. The formed metal chelates were then filtered and washed several times with bidistilled water and methanol until the filtrate become colorless, then the chelates were dried over anhydrous $\mathrm{CaCl}_{2}$.

\section{Apparatus and procedure}

Elemental analysis were performed in the Microanalytical Center of Cairo University. The metal content of the chelates was determined after wet decomposition as previously described ${ }^{(7)}$ followed by EDTA titration ${ }^{(8,9)}$ (Table 1) .

Conductometric titrations of $50 \mathrm{ml} 5 \times 10^{-3} \mathrm{M}$ ligand solution of ethanolwater $(75 \% \mathrm{v} / \mathrm{v})$ were carried out with $5 \times 10^{-4} \mathrm{M}$ of $\mathrm{Fe}(\mathrm{III}), \mathrm{Co}(\mathrm{II}), \mathrm{Ni}(\mathrm{II})$ and $\mathrm{Cu}$ (II) ions. Also, the conductivity measurement on solid chelates in DMF were carried out using a YSI model 32 conductance meter.

The infrared spectra of the ligands as well as of the chelates were obtained by applying the $\mathrm{KBr}$ disc technique using Perkin-Elmer 1430 infrared spectrometer. The visible spectra of free ligand and their chelates were measured by applying Nujol mull and DMF technique using Jascow 530 spectrophotometer with $10 \mathrm{~mm}$ matched Quartz Cell.

Thermogravimetric analysis of chelates were achieved using Schimadzu thermal analyzer. The weight loss was measured from ambient temperature up to $700^{\circ} \mathrm{C}$ ramped at $10^{\circ} \mathrm{C} / \mathrm{min}$ in air atmosphere. The magnetic susceptibility was measured with a Gouy's set up at room temperature using $\mathrm{Hg}\left[\mathrm{Co}(\mathrm{NCS})_{4}\right]$ as calibrating agent and calculations were made using computed values of Pascal's constants.

Egypt. J. Chem. 53, No. 3 (2010) 


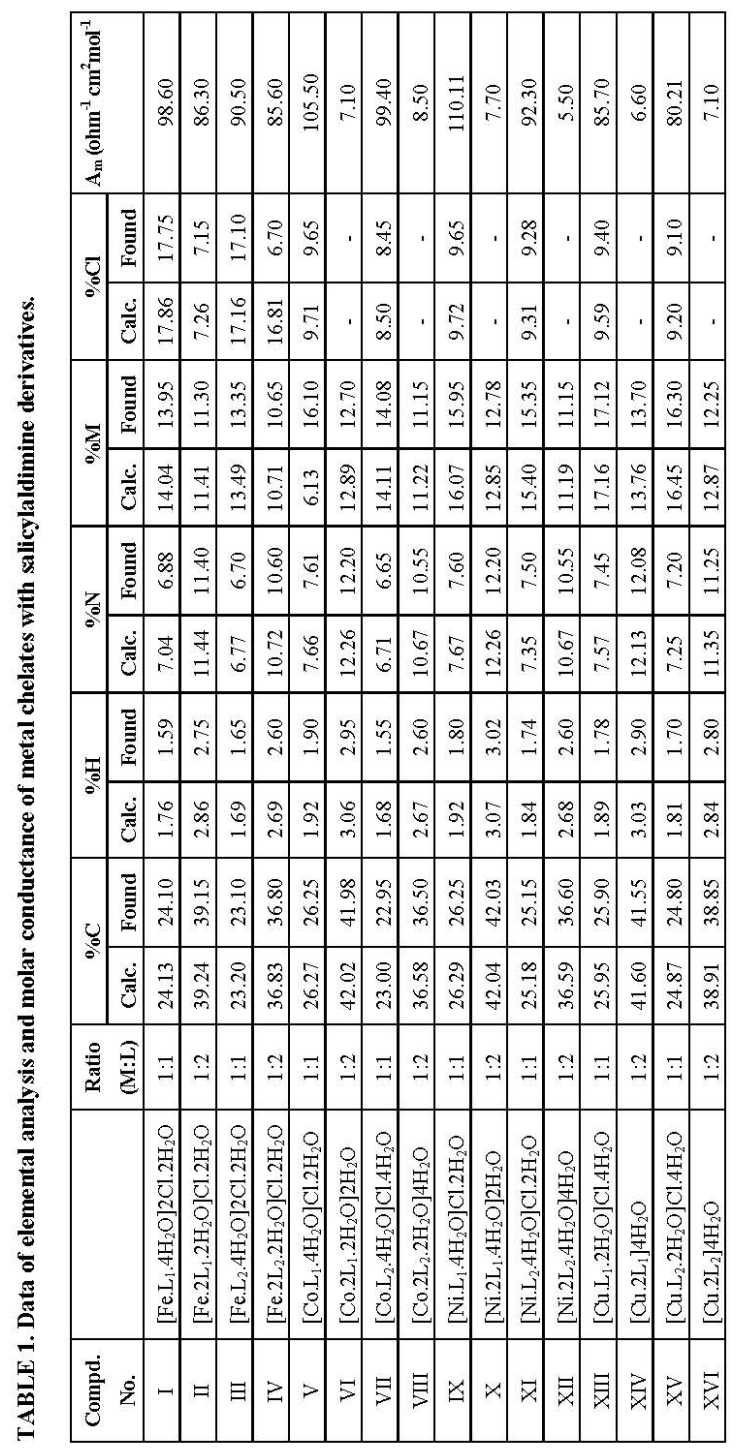

Egypt. J. Chem. 53, No. 3 (2010) 


\section{Results and Discussion}

The conductometric titration curves of the ligands under investigation with $\mathrm{Fe}(\mathrm{III}), \mathrm{Co}(\mathrm{II}), \mathrm{Ni}(\mathrm{II})$ and $\mathrm{Cu}(\mathrm{II})$ ions exhibit two inflection at molar ratios of 0.5 and 1.0 indicates the formation of (1:1) and ( 1:2) (M:L) complexes species in solution.

The formation constants of the complexes were also studied as a function of the ionic radii of the metal ions (Fig.2). The relation between the stability constants of the respective complexes and ionic radii of transition metal ions shows that the $\mathrm{Fe}^{3+}$-complexes have the highest stability compared to the other complexes (Table 2).
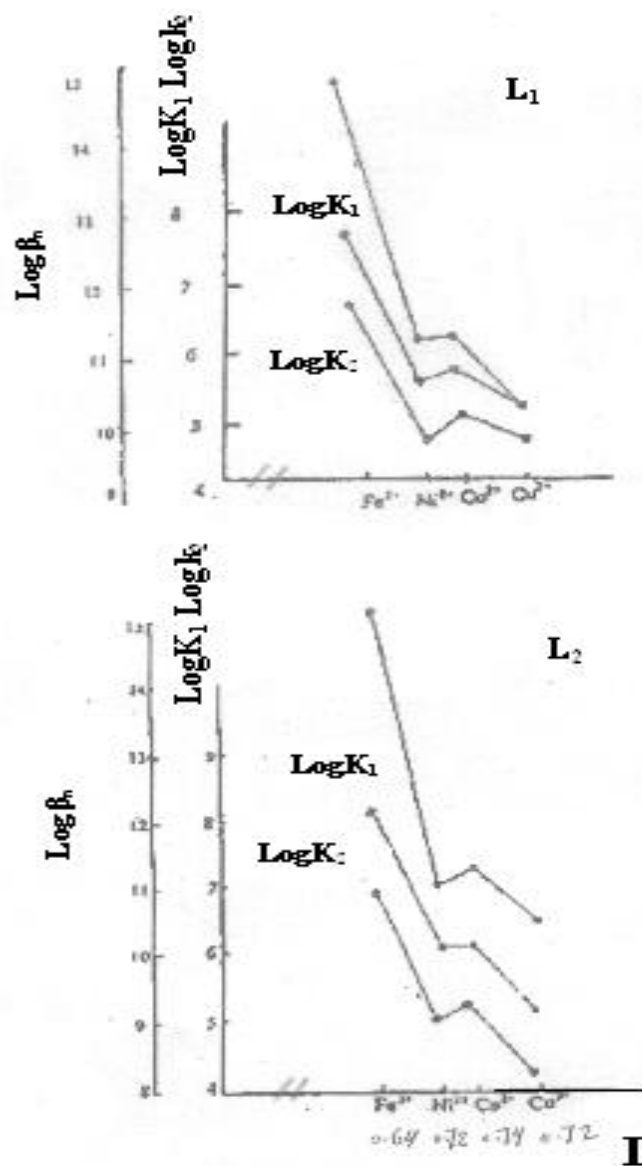

\section{Ionic Radii}

Fig. 2. The stability of the complexes as a function of the ionic radii of the metal ion. 
TABLE 2. Potentiometric data of the ligands and its complexes with transition metal ions.

\begin{tabular}{|c|c|c|c|c|c|c|c|}
\hline \multirow{2}{*}{ Compd } & \multirow{2}{*}{$\begin{array}{c}\text { Ionic } \\
\text { radii } \mathbf{A}\end{array}$} & \multicolumn{5}{|c|}{ Pog } \\
\cline { 3 - 8 } & & $\mathbf{K}_{\mathbf{a}}^{\mathbf{H}}$ & $-\Delta \mathbf{G}^{*}$ & $\begin{array}{c}\mathbf{L o g} \\
\mathbf{K}_{\mathbf{1}}\end{array}$ & $\begin{array}{c}\mathbf{L o g} \\
\mathbf{K}_{\mathbf{2}}\end{array}$ & $\begin{array}{c}\mathbf{L o g} \\
\boldsymbol{\beta}_{\mathbf{n}}\end{array}$ & $\begin{array}{c}-\Delta \mathbf{G}^{*} \\
\mathbf{C a l} / \mathbf{m o l e}\end{array}$ \\
\hline $\mathrm{L}_{1}$ & - & 8.2 & 11.14 & - & - & - & - \\
\hline $\mathrm{Fe}^{3+}$ & 0.64 & - & - & 8.11 & 6.90 & 15.01 & 20.40 \\
\hline $\mathrm{Co}^{2+}$ & 0.74 & - & - & 6.01 & 5.23 & 11.24 & 15.27 \\
\hline $\mathrm{Ni}^{2+}$ & 0.72 & - & - & 5.98 & 5.01 & 10.99 & 14.93 \\
\hline $\mathrm{Cu}^{2+}$ & 0.72 & - & - & 6.23 & 4.23 & 10.45 & 14.21 \\
\hline $\mathrm{L}_{2}$ & - & 10.2 & 13.86 & & & & \\
\hline $\mathrm{Fe}^{3+}$ & 0.64 & - & - & 8.14 & 7.10 & 15.24 & 20.71 \\
\hline $\mathrm{Co}^{2+}$ & 0.74 & - & - & 6.12 & 5.48 & 11.60 & 15.76 \\
\hline $\mathrm{Ni}^{2+}$ & 0.72 & - & - & 6.46 & 5.12 & 11.58 & 15.74 \\
\hline $\mathrm{Cu}^{2+}$ & 0.72 & - & - & 5.48 & 5.10 & 10.58 & 14.38 \\
\hline
\end{tabular}

\section{IR-spectra}

The mode of bonding of the Schiff base to the transition metal ions was elucidated by investigating the IR spectra of the chelates $(1: 1)$ and $(1: 2)(\mathrm{M}: \mathrm{L})$ as compared to those of the free ligands (Fig. 3). The broad bands observed at 3302 and $3170 \mathrm{~cm}^{-1}$, assigned to $\mathrm{v}(\mathrm{OH})$ in the spectra of the free ligands 1 and 2 , respectively ; their position is shifted to higher wavenumbers $10-20 \mathrm{~cm}^{-1}$ in their complexes. This behaviour may be attributed to the participation of the phenolic $\mathrm{OH}$ group of the Schiff base in chelation with the metal ion. The bending $\delta(\mathrm{OH})$ bands at 1353 and $1363 \mathrm{~cm}^{-1}$ of the free ligands exhibit a shift to $5-10 \mathrm{~cm}^{-1}$ to lower wavenumber values on complexation. This behaviour is due to the liberation of the proton from phenolic $\mathrm{OH}$ group of the ligand through chelation with metal ions. The $v(\mathrm{C}=\mathrm{O})$ band at $1656 \mathrm{~cm}^{-1}$ for ligand 1 and $v(\mathrm{C}=\mathrm{S})$ at 1353 $\mathrm{cm}^{-1}$ for ligand 2 , exhibit no shift of the wavenumbers on complexation which may not be taken as evidence for participation of $\mathrm{C}=\mathrm{O}$ or $\mathrm{C}=\mathrm{S}$ group in coordination. The $v(\mathrm{C}=\mathrm{N})$ bands at 1622 and $1615 \mathrm{~cm}^{-1}$ for ligand 1 and 2 , respectively ${ }^{(10)}$ exhibit a shift of $10-20 \mathrm{~cm}^{-1}$ to lower or higher wavenumbers on complexation which may be taken as evidence for the participation of azomethine nitrogen in chelate formation. The new bands appearing in the range of 530-500 $\mathrm{cm}^{-1}$ are assigned to $v(\mathrm{M}-\mathrm{N}) ; v(\mathrm{M}-\mathrm{O})$ and $v(\mathrm{M}-\mathrm{Cl})$, respectively ${ }^{(11,12)}$. The band at $3000-3300 \mathrm{~cm}^{-1}$ in the spectra of chelates may be due to the $\mathrm{vOH}$ vibration of coordinate water molecules ${ }^{(13)}$. 


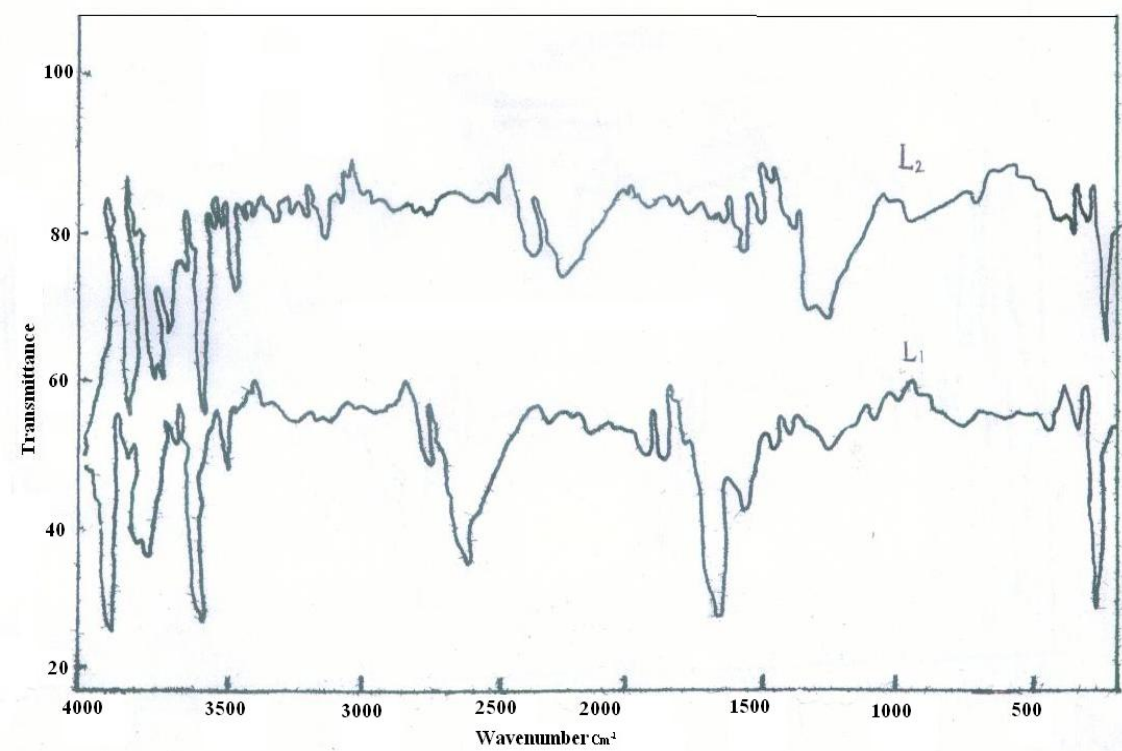

Fig. 3. IR spectra of $\mathrm{N}$ - salicylaldimine-2- urea $\left(\mathrm{L}_{1}\right)$ and $\mathrm{N}$ - salicylaldimine-2thiourea $\left(\mathbf{L}_{2}\right)$.

The electronic spectra and magnetic measurements

The electronic absorption spectra of the free ligands and their complexes under investigation were performed in dimethyl formamide as solvent. The electronic spectra of the free ligands (1 and 2) display three bands, the first one at $38610-39216 \mathrm{~cm}^{-1}$ which attributed to transition within the phenyl moiety, the second band at $35714-37037 \mathrm{~cm}^{-1}$ which may be due to the $\mathrm{n}-\pi^{*}$ transition of $\mathrm{C}=\mathrm{O}$ and $\mathrm{C}=\mathrm{S}$ group, the later band at $30488-31250 \mathrm{~cm}^{-1}$ which attributed to the charge transfer within the ligand molecules.

The electronic spectra of the chelates $\mathrm{Fe}(\mathrm{III}), \mathrm{Co}(\mathrm{II})$ and $\mathrm{Ni}(\mathrm{II})$ with the ligands (1 and 2) (1:1) (M:L) as well as (1:2) (M:L), respectively, show bands at $20739-24101 \mathrm{~cm}^{-1}$, which can be assigned to ${ }^{2} \mathrm{~A}_{1 \mathrm{~g}} \rightarrow{ }^{2} \mathrm{~T}_{2 \mathrm{~g}}$ transition for Fe(III), ${ }^{4} \mathrm{~T}_{1 \mathrm{~g}}(\mathrm{~F}) \rightarrow{ }^{4} \mathrm{~T}_{1 \mathrm{~g}}(\mathrm{P})$ for $\mathrm{Co}(\mathrm{II})$ and ${ }^{3} \mathrm{~A}_{2 \mathrm{~g}}(\mathrm{~F}) \rightarrow{ }^{3} \mathrm{~T}_{\mathrm{lg}}(\mathrm{P})$ for Ni(II) chelates.

The high intesnity of the band and the paramagnetic nature support the distortion of octahedral geometry for these chelates ${ }^{(14,15)}$. On the other hand, the $\mathrm{Cu}(\mathrm{II})$ chelates with the ligands (1 and 2) (1:1) or (1:2) (M:L), respectively show a broad band at $21281 \mathrm{~cm}^{-1}$ with the maxima at $21200 \mathrm{~cm}^{-1}$ which has been assigned to ${ }^{2} \mathrm{~B}_{\mathrm{lg}} \rightarrow{ }^{2} \mathrm{E}_{\mathrm{g}}$ transition, the intensity of the bands and the magnetic moment values support square-planar geomtry for these chelates ${ }^{(16,17)}$ (Table 3). 


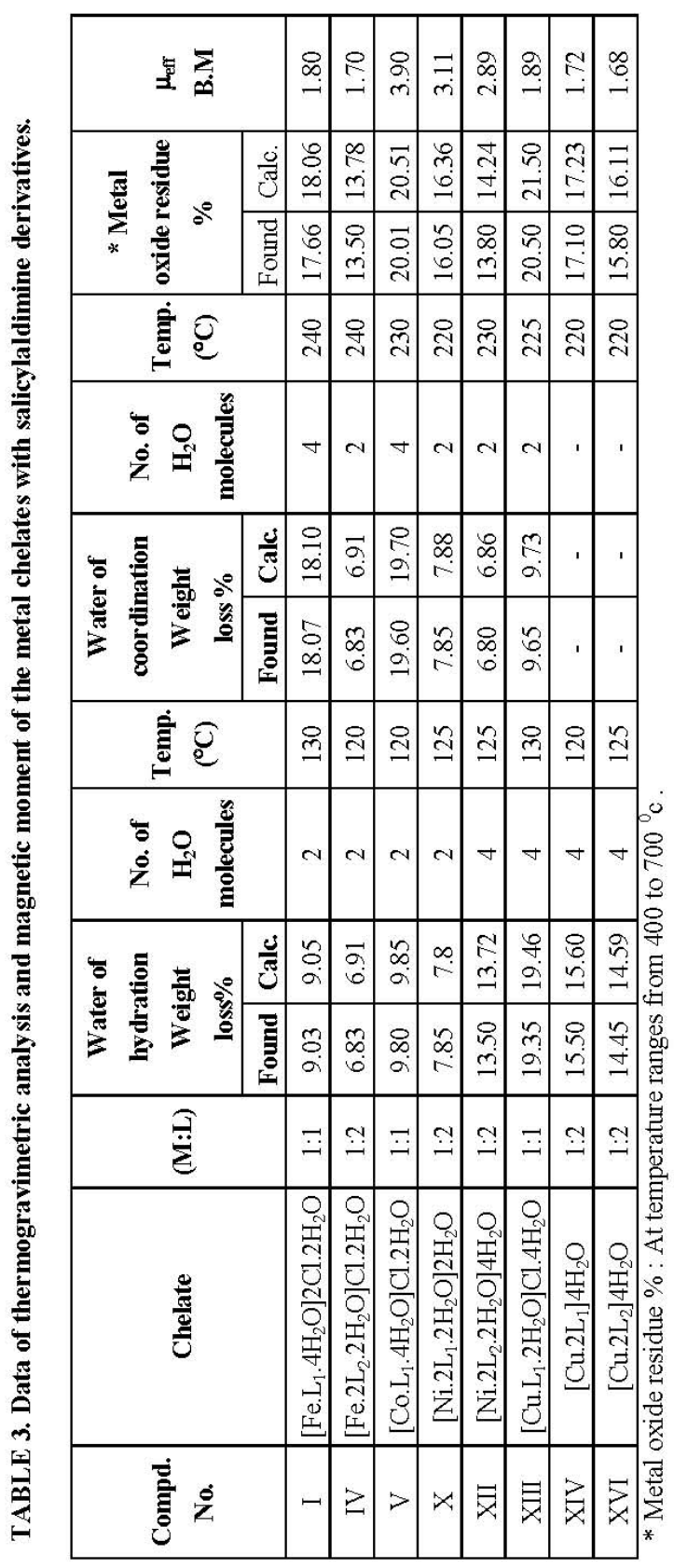

Egypt. J. Chem. 53, No. 3 (2010) 


\section{Thermogravimetric analysis}

The thermal analyses were performed for the chelates of $\left[\mathrm{Fe} . \mathrm{L}_{1} \cdot 4 \mathrm{H}_{2} \mathrm{O}\right.$ ] $2 \mathrm{C} 1.2 \mathrm{H}_{2} \mathrm{O}(\mathrm{I}), \quad\left[\mathrm{Fe} .2 \mathrm{~L}_{2} .2 \mathrm{H}_{2} \mathrm{O}\right] \quad \mathrm{C} 1.2 \mathrm{H}_{2} \mathrm{O}$ (IV), [Co. $\mathrm{L}_{1}$. $\left.4 \mathrm{H}_{2} \mathrm{O}\right] \quad \mathrm{C}^{2} .2 \mathrm{H}_{2} \mathrm{O}(\mathrm{V})$, [Ni.2L, $\left.2 \mathrm{H}_{2} \mathrm{O}\right] 2 \mathrm{H}_{2} \mathrm{O}(\mathrm{X})$, [Ni.2 $\left.2 \mathrm{~L}_{2} \cdot 2 \mathrm{H}_{2} \mathrm{O}\right] 4 \mathrm{H}_{2} \mathrm{O}$ (XII), [Cu. $\left.\mathrm{L}_{1} .2 \mathrm{H}_{2} \mathrm{O}\right] \mathrm{C} 1.4 \mathrm{H}_{2} \mathrm{O}(\mathrm{XIII})$, [Cu.2L,] $4 \mathrm{H}_{2} \mathrm{O}(\mathrm{XIV})$ and $\left[\mathrm{Cu}_{2} 2 \mathrm{~L}_{2}\right] 4 \mathrm{H}_{2} \mathrm{O}(\mathrm{XVI})$, respectively. From TG curves, the weight losses were calculated for the different steps and compared with those theoretically calculated for the suggested formulas based on the results of the elemental analyses as shown in Table 1. The first weight loss at temperature up to $130{ }^{\circ} \mathrm{C}$ is attributed to the loss of hydrated water molecules for all complexes. Whereas, the second step of the weight loss within the temperature range $130-240{ }^{\circ} \mathrm{C}$ which is assignable to coordinated water molecules in the inner sphere of the metal chelates. For the (1:1) (M:L) chelates of $\mathrm{Fe}(\mathrm{III}), \mathrm{Co}(\mathrm{II})$ and $\mathrm{Cu}$ (II) with the ligand $\left(\mathrm{L}_{1}\right)$ and $(1: 2)(\mathrm{M}: \mathrm{L})$ chelates of $\mathrm{Fe}(\mathrm{III}), \mathrm{Ni}(\mathrm{II})$ and $\mathrm{Cu}(\mathrm{III})$ with the ligand $\mathrm{L}_{2}$ or $\mathrm{L}_{1}$, the weight losses are about 9.03, 9.80 and $19.35 \%$ for (1:1) (M:L), respectively and this can be attributed to the loss of two water molecules. That is eliminated at temperature up to $130{ }^{\circ} \mathrm{C} ; 18.07,19.6$ and $9.56 \%$ weight (loss is assignable to four water coordinated molecules for complexes (I,III and V) and to two water coordinated for complex (XIII), respectively), within the temperature range $130-240{ }^{\circ} \mathrm{C}$.

On the other hand, for (1:2) (M:L) chelates of $\mathrm{Fe}(\mathrm{III}), \mathrm{Ni}(\mathrm{II})$ and $\mathrm{Cu}(\mathrm{II})$ with ligands $\mathrm{L}_{2}$ and $\mathrm{L}_{1}$ periodically, the weight losses are $6.83,7.85,13.5,15.50$ and $14.45 \%$, respectively; which are attributed to the removal of two hydrated water molecules of complexes (IV and X) and four hydrated water molecules of complexes XII, XIV and XVI, respectively. The weight losses are about 6.83, 7.85 and $6.80 \%$ for the complexes (IV, X and XII), respectively, attributed also to the removal of two coordinated water molecules in these chelates of $\mathrm{Fe}(\mathrm{III})$ and $\mathrm{Ni}(\mathrm{II})$, but for chelates of $\mathrm{Cu}$ (II) no participation of coordinated water molecules within the complexes XIV and XVI, respectively.

The percentage of metal oxide was found experimentally as the end product from TG-curves at temperature range from $400-700^{\circ} \mathrm{C}$, the metal oxide residue amounted to $17.66,20.01$ and $20.50 \%$ for (1:1) (M:L) complexes (I, V and XIII), respectively, and the corresponding calculated values are 18.06, 20.51 and $21.50 \%$, respectively. The metal oxide percentage of the (1:2) (M:L) complexes (IV, X, XII, XIV and $\mathrm{XVI}$ ), respectively was found to be $13.50,16.05,13.80,17.10$ and $15.80 \%$, respectively, which are in good agreement with calculated ones for the suggested formula in Table 3. The following scheme, may be suggested for the thermal degradation of the chelates with $\mathrm{Fe}(\mathrm{III}), \mathrm{Co}$ (II), $\mathrm{Ni}$ (II) and $\mathrm{Cu}(\mathrm{II})$, respectively. 


$$
\begin{aligned}
& {\left[\mathrm{M} \mathrm{ml}_{1 \mathrm{or} 2} \cdot\left(\mathrm{H}_{2} \mathrm{O}\right)_{\mathrm{n}}\right] \times \mathrm{Cl} \mathrm{yH}_{2} \mathrm{O} \stackrel{60-130^{\circ} \mathrm{C}}{\longrightarrow}\left[\mathrm{M}^{-m_{10 r} \cdot} \cdot\left(\mathrm{H}_{2} \mathrm{O}\right)_{\mathrm{n}}\right] \mathrm{xCl}+\mathrm{yH}_{2} \mathrm{O}}
\end{aligned}
$$

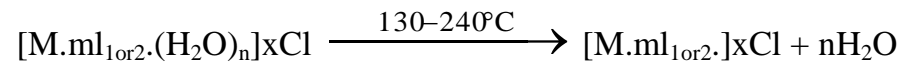

$$
\begin{aligned}
& \text { unstable intermediate } \\
& \text { Unstable intermediate } \stackrel{>400^{\circ} \mathrm{C}}{\longrightarrow} \mathrm{MO}(\mathrm{M}=\mathrm{Fe}, \mathrm{Co}, \mathrm{Ni} \text { and } \mathrm{Cu}) \\
& \text { where }(\mathrm{n}=2 \text { or } 4, \mathrm{x}=1 \text { or } 2, \mathrm{y}=2 \text { or } 4)
\end{aligned}
$$

Scheme 1 .

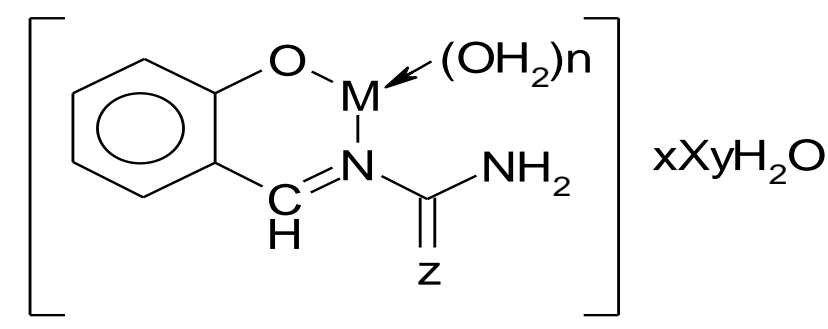

$\mathrm{n}=2$ or $4, \mathrm{x}=1$ or $2, \mathrm{y}=2$ or $4, \mathrm{X}=\mathrm{Cl}, \mathrm{Z}=\mathrm{O}$ or $\mathrm{S}$ and a- M; $\mathrm{Fe}(\mathrm{III}), \mathrm{Co}(\mathrm{II}), \mathrm{Ni}(\mathrm{II})$ and $\mathrm{Cu}(\mathrm{II})$ (I:I) (M:L)

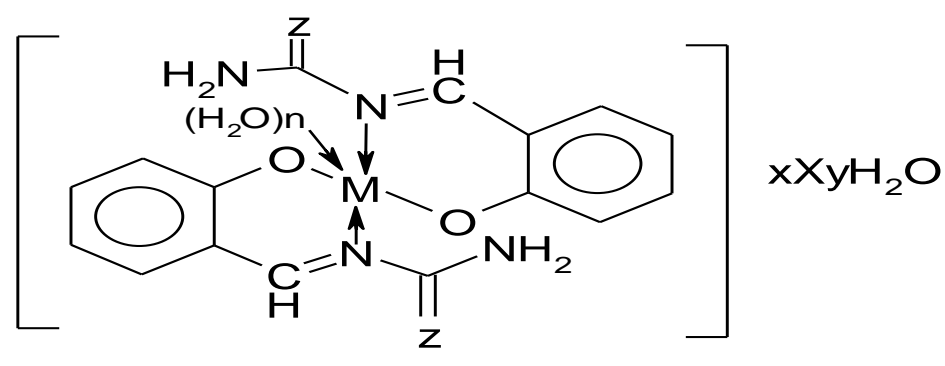

$$
\mathrm{n}=0 \text { or } 2, \mathrm{x}=1 ; \mathrm{y}=4, \mathrm{X}=\mathrm{Cl} \text {, }
$$

b- $\mathrm{M} ; \mathrm{Fe}(\mathrm{III}), \mathrm{Co}(\mathrm{II}), \mathrm{Ni}(\mathrm{II})$ and $\mathrm{Cu}(\mathrm{II})$ (I:2) (M:L)

Fig. 4 ( $a, b)$ : Suggested structural formula of complexes.

\section{Conclusions}

Based on the elemental analysis; potentiometric and conductometric measurements; spectral, thermogravimetric analysis and magnetic moments measurements of the metal ions complexes of salicylaldimine derivatives, the following conclusions are supported: 
i-The salicylaldimine derivatives with $\mathrm{Fe}(\mathrm{III}), \mathrm{Co}(\mathrm{II}), \mathrm{Ni}(\mathrm{II})$ and $\mathrm{Cu}(\mathrm{Il})$ ions are formed in ratios (1:1) and (1:2) (M:L) in solution as well as in the solid state.

ii-The electronic spectra data and magnetic moment value of the $\mathrm{Fe}(\mathrm{III}), \mathrm{Co}$ (II), and $\mathrm{Ni}(\mathrm{II})$ chelates with salicylaldimine derivatives show octahedral arrangement; but in case of $\mathrm{Cu}$ (Il) chelate show square-planar arrangement (Fig. 4- a,b)

iii-The most important conclusion drawn from the above investigation is that the mono basic bidentate ligands is coordinated to the metal ions through the $\mathrm{O}$ and $\mathrm{N}$ as donor atoms in (1:1) as well as (1:2) (M:L) chelates. Also, the structure of chelates is constructed.

\section{References}

1. El- Bahnasawy, R.M., El-Tabl, A.S., El-Shereafy, E., Kashar, T.I. and Issa, Y.M., Polish J.Chem. 73, 1952 (1999) .

2. Straszko, J., Olszak, M.H. and Mozejko, J., Thermochim. Acta, 292, 145 (1997) .

3. Hsu, C.K., Lee, J.S. and Huang, C.W., Thermal Anal, 51, 295 (1998).

4. Mishra, A.P. and Mahimo, K., J. Indian Chem. Soc. 77, 370 (2000) .

5. Jang, Y.J., Lee, U. and Koo, B.K., Bull. Korean Chem. Soc. 26, 925 (2005) .

6. Bahad, P.J., Bhave, N.S. and Aswar, A.S., J. Indian Chem. Soc. 77, 363-366 (2000).

7. Macdonald, A.M.G. and Sirichanya, P., Microchem. J. 14, 199 (1969).

8. Welcher, F. J., In : The Analytical Uses of Ethylendiaminetetraacetic Acid. D.Van Nostrand (Ed.), New York (1958) .

9. Bassett, J. Denney, R.C. Jeffery, G.H. and Mendham, J., Vogel's Textbook of Quantitative Inorganic Analysis. $4^{\text {th }}$ ed. Longman, London pp.257-344 (1978) .

10. El-Sonbati, A., Transition polymer complexes ,XVII. Thermal stability of poly (5-Vinyl salicylidine)-2-aminophenol with transition metal chelates. Met. Chem. 16, 45(1999).

11. El-Tabl, A.S ., J. Chem.Res. 5, 529 (2002).

12. El- Motaleb, A., Ramedan, M., Sawodny, W., El-Baradie, H.F. and Gabe, M., Transition synthesis and characterization of $\mathrm{Ni}+2$ - complexes with symmetrical tetradentate $\mathrm{N}_{2} \mathrm{O}_{2}$ naphthaldimine ligands. Met.Chem. 22, 211(1997).

13. Hegazy, W.H., Synthesis and structural studies of some B - diketone phenyle hydrazones and their complexes with $\mathrm{Co}^{+2}, \mathrm{Ni}^{+2}$ and $\mathrm{Cu}^{+2}$. Monat. Sh. Chem. 132, 639 (2001).

Egypt. J. Chem. 53, No. 3 (2010) 
14. Prohu, G.V. and Venkappayya, D., J. Indian Chem. Soc. 72 , 511(1995).

15. Cotton, F.A. and Wilkinson, G., "Advanced Inorganic Chemistry", Interscience, New York (1966).

16. Faniran, J.A. Patel, K.S. and Nelson, L.O., Physico- chemical studies of metal Bdiketonates infrared spectra of 1-(3-pyridyl)- 1,3- butanedione and its divalentmetal complexes. J. Inorg. Nucl. Chem. 38,77 (1976).

17. Atkins, R., Brewer, G., Kokot, E., Mockier, G.M. and Sinn, E., Inorg. Chem. 24,127(1985).

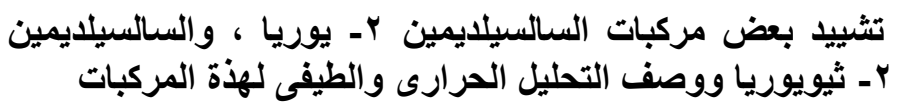

ابراهيم السيد أحمد ، طلعت يونس محمد و مصطفى محمود مصطفى

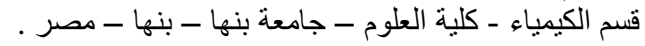

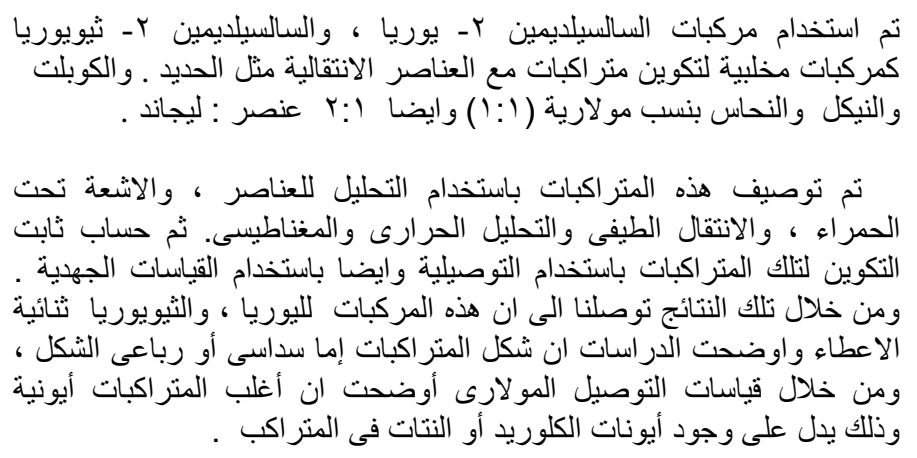

